\title{
Conservation genetics of the capercaillie in Poland - estimating the size of the Tatra National Park population by the genotyping of non-invasive samples
}

\author{
Robert RUTKOWSKI ${ }^{1}$, Beata DULISZ ${ }^{2}$, Sebastian SZCZEPAŃSKI ${ }^{3}$, Jacek J. NOWAKOWSKI ${ }^{2}$, \\ TOMASZ ZWIJACZ-KOZICA ${ }^{4}$ and Piotr KRZAN ${ }^{4}$ \\ ${ }^{1}$ Museum and Institute of Zoology, Polish Academy of Sciences, Wilcza 64, 00-679 Warszawa, Poland; \\ e-mail: robertrut@miiz.waw.pl (corresponding author) \\ ${ }^{2}$ University of Warmia and Mazury in Olsztyn, Faculty of Biology and Biotechnology, \\ Plac Lódzki 3, 10-727 Olsztyn, Poland \\ ${ }^{3}$ Warsaw University of Life Sciences-SGGW, Faculty of Animal Sciences, Ciszewskiego 8, 02-786 Warszawa, Poland \\ ${ }^{4}$ Tatra National Park, Kuźnice 1, 34-500 Zakopane, Poland
}

\begin{abstract}
Knowledge about population size is of high importance for conservationists. We used non-invasively collected samples and microsatellite genotyping to estimate the size of the Tatra National Park population of the endangered capercaillie Tetrao urogallus. This population is one of the most important strongholds of the species in Poland. In 2016 over 150 samples (faeces and feathers) of the capercaillie were collected throughout area of the Tatra National Park. Then, DNA was extracted and genetic profiles were evaluated, using nine microsatellite markers. We obtained 81 reliable genotypes. Among them, 34 unique genotypes were found, corresponding to Minimum Number of individuals Alive in the investigated population. Application of capture-recapture models in the R package Capwire indicated, that the area was inhabited by approx. 54 birds, whereas regression model suggested presence of 36-64 individuals. Previous field surveys suggested that the number of birds in the Tatra National Park is about 50. Hence, we assumed that genetic tagging of non-invasive samples performs well in estimating the abundance of the capercaillie in the investigated population.
\end{abstract}

Key words: Tetrao urogallus, population size, genetic tagging, microsatellites, non-invasive samples

\section{INTRODUCTION}

The field of conservation genetics investigates genetic processes, which affect populations of endangered species and identifies factors influencing the level of genetic diversity and distribution of genetic diversity among populations (Amos \& Balmford 2001, Hedrick 2001, Sarre \& Georges 2009, Kristensen et al. 2010). Molecular techniques are applied to broaden our knowledge about biology, ecology, phylogeography and the taxonomy of endangered species (Haig et al. 2011, Martinez-Cruz 2011). The results of such investigations may have important implications for the planning of conservation programmes and the management of the endangered populations of a wide range of species (e.g. DeSalle \& Amato 2004, Morin et al. 2010, McCartney-Melstad \& Shaffer 2015). Investigating individuals at the level of their genes also allows unique genetic profiles to be created. This, in turn, combined with polymorphic molecular markers, such as microsatellites and non-invasive sampling, could be used to track a particular specimen in a field without the necessity of direct observation or tagging (Taberlet et al. 1999, Selkoe \& Toonen 2006). Hence, this strategy is often used in the case of endangered and/or timid species, increasing the important role molecular population genetics and molecular ecology now play in modern conservation planning.

The capercaillie (Tetrao urogallus L., 1758) is one of the most threatened woodland grouse in Europe (Storch 2007a, BirdLife International 2012). During the last few decades, 
populations of the capercaillie have declined throughout their range (Storch 2007b). In Poland, the number of birds has dropped from 2,500 at the beginning of the 20th century to as little as 400-500 individuals. Currently, the Polish population is scattered in four isolated areas: the Polish part of the Western Carpathians, Solska Forest, Augustów Forest and Lower Silesian Forest, in which population is of the reintroduced status (Rutkowski et al. 2017 and references therein). The need for the active protection and management of existing populations has stimulated several genetic studies of these birds, applying molecular techniques (Rutkowski et al. 2007). The characterisation of species-specific microsatellite markers and the development of laboratory methods allowing for the use of non-invasive samples as a source of genetic material (Segelbacher et al. 2000, Segelbacher 2002, Regnaut et al. 2006b) provided insight into the ecology of the species (Mäki-Petäys et al. 2007, Regnaut et al. 2006a, Segelbacher et al. 2007, 2008) as well as large body of research work focused on its population genetics (e. g. Segelbacher et al. 2003, Liukkonen-Anttila et al. 2004, Bajc et al. 2011, Rutkowski et al. 2005, 2017). Indeed, molecular techniques and non-invasive sampling were used to estimate the population size of some populations (Jacob et al. 2010, Mollet et al. 2015, Rutkowski et al. 2015).

The Western Cartpathians are the most important stronghold of the capercaillie in Poland. The size of this population is estimated at 300 individuals, and most importantly, it is probably connected with the capercaillie population in Slovakia (Żurek \& Armatys 2011). Nonetheless, reliable information about the actual population size is still lacking. Field surveys are interlaced with some errors, as rarely every member of the population is detected, leading to underestimates of the population size (Mollet et al. 2015). In this study, we used microsatellite genotyping of non-invasive samples to estimate the Minimum Number of individuals Alive (MNA) of the capercaillie population from the Tatra National Park in the Western Carpathians, and used this data to estimate the size of the population based on genetic tagging (analogous to the conventional Capture-Mark-Recapture approach).

\section{MATERIAL AND METHODS}

\section{Sample collection}

Non-invasive samples - faeces and feathers of the capercaillie - were collected during field surveys in 2016. Surroundings of the known leks were surveyed, as well as regions of the Park, where the capercaillie has been frequently observed. Searching for faeces samples were conducted between February and May, during snow retention. Additionally, some feather samples were collected between June and September 2016. After being collected in the field, the faeces were immediately froze and stored in a freezer at $-22^{\circ} \mathrm{C}$ until extraction. The feathers were stored in paper envelopes or plastic vials, while after delivery to the laboratory, they were kept in a freezer at $-4^{\circ} \mathrm{C}$. In total, 156 samples were collected, including 150 faeces and 6 feathers. The distribution of the sampling sites is presented in Fig. 1.

\section{Laboratory procedures}

DNA from faeces was extracted using the NucleoSpin Soil Kits (MACHEREY-NAGEL, distributed in Poland by AQUA LAB), using the manufacturers' protocol, except for the fact that a double volume of lysate was used for each sample. DNA extractions from feathers were performed using a NucleoSpin Tissue Kits (MACHEREY-NAGEL) in line with the standard protocol. As the material constituted non-invasive samples, several measures were taken, as it was described in the paper by Rutkowski et al. (2017), in association with the DNA isolation process in order to minimise problems of contamination.

All the extracts were made subject to PCR. We amplified 9 microsatellite loci, i.e. TuT1, TuT2, TuT3, TuT4, TTT1, Bg12, Bg16 and Bg18 (tetranucleotide repeats) and TuD4 
(dinucleotide repeat) (Segelbacher et al. 2000, Caizergues et al. 2001, Piertney \& Höglund 2001). Microsatellites were amplified in two multiplex reactions, i.e. MIX A containing primers for amplification of Bg16, TTT1, TuT2 and Bg12 loci, and MIX B: TuD4, TuT1, TuT4, TuT3 and Bg18. Each forward primer was labelled with one of the fluorescent dyes Dye2, Dye3 and Dye4 (from WellRead Dyes, distributed in Poland by Sigma-Aldrich Poland). The reaction mixture contained $1.5 \mu \mathrm{l}$ of the mixture of primers ('forward' and 'reverse' for each locus, $2 \mathrm{pmol} / \mu \mathrm{l}$ ), $7.5 \mu \mathrm{l}$ PCR MasterMix (QIAGEN, distributed in Poland by Syngen Biotech), and 2-3 $\mu \mathrm{l}$ of DNA extract, depending on the source of the DNA: $2 \mu 1$ of extract was used in the case of feathers and $3 \mu \mathrm{l}$ in the case of DNA obtained from faeces. Additionally, in the latter case we also added $0.3 \mu \mathrm{l}$ of PCR anti-inhibitor (DNA GDAŃSK, distribution in Poland by Blirt). The reaction mix was made up to $15 \mu \mathrm{l}$ of the final volume with water for PCR (SIGMA-ALDRICH, distribution in Poland by Sigma-Aldrich Poland). The reactions were performed in the following conditions: $15 \mathrm{~min}$ at $95^{\circ} \mathrm{C}, 40$ cycles of $30 \mathrm{~s}$ at $94^{\circ} \mathrm{C}, 90 \mathrm{~s} 57^{\circ} \mathrm{C}$, $90 \mathrm{sec} 72^{\circ} \mathrm{C} 1$ cycle: $30 \mathrm{~s}$ at $94^{\circ} \mathrm{C}, 90 \mathrm{~s} 57^{\circ} \mathrm{C}, 10 \mathrm{~min}$ at $72^{\circ} \mathrm{C}$. Controlling for contamination during the course of PCR was performed as described previously (Rutkowski et al. 2017). The genotyping analyses were performed using a CEQ 8000 sequencer (BECKMAN COULTER, distributed in Poland by Comesa-Polska).

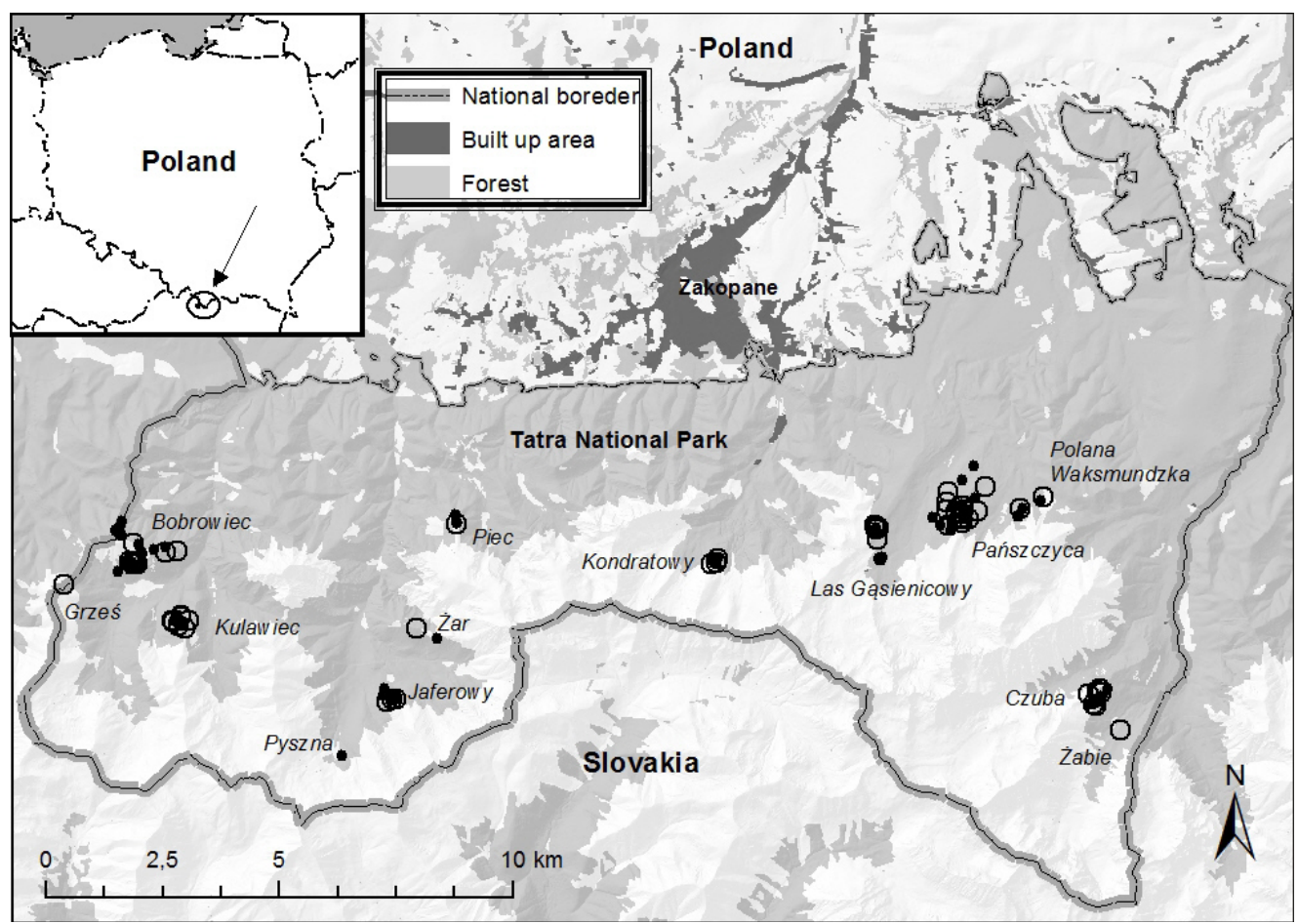

Fig 1. Distribution of sampling sites throughout area of the Polish Tatra National Park; (black dotes - genotyped samples, empty circles - undetermined samples).

To obtain reliable genetic data, several measures were taken to avoid genotyping errors (Rutkowski et al. 2017). Briefly, all PCR reactions were repeated at least twice. All extracts lacking the PCR product in the two reactions were excluded from further analysis. Equally, extracts with two identical genotypes in both independent PCRs were classified as successfully 
genotyped. All extracts showing signs of contamination (more than two microsatellite alleles at particular loci) were excluded from further analysis. Two additional PCRs were performed in the case of differences between genotypes obtained in the two first PCRs, which could be explained by typical technical problems observed frequently during the microsatellite genotyping of non-invasive samples (i.e. 'allelic drop-out' or 'false alleles'). Consensus genotypes were then created on the basis of the genotypes obtained in all four reactions. The extracts showing evidently different genotypes in successive PCR reactions were excluded from further analysis.

\section{Statistical analysis}

We assumed that the presence of identical microsatellite genotypes in two or more independent samples attested to the samples belonging to the same individual. Comparisons of genotypes were performed using GenAlEx v. 6.501 (Peakall \& Smouse 2006, 2012). We assumed that the number of identified unique genotypes reflects the Minimum Number of individuals Alive (MNA) in the investigated population from the Tatra National Park. Additionally, we attempted to estimate the size of the whole population. Two methods were used: (i) probabilistic estimation of the number of birds inhabiting the study area, based on the algorithms of a R package Capwire (Miller et al. 2005). Capwire applies capture-recapture models, which allow individuals to be sampled multiple times per session to estimate population size from non-invasive samples (Pennell et al. 2013). We used the Two-Innate Rates Model (TRIM, different probability of detecting individuals).This method, compared to other capture-recapture methods, yields better results when samples are collected continuously and the population is relatively small. Also, the method does not need to divide the sampling period into sessions and results in a relatively narrow confidence interval (Miller et al. 2005). The TRIM model was used because we assumed that in the case of the capercaillie, the probability of detecting males and females during the display period will vary widely, due to the frequency of residence and behavior of the birds during mating at a lek. (ii) Based on the assumption that more and more new individuals are being detected over time, a regression model of the relationship between the number of genotypes detected in the next days of the study season was created:

POPULATION SIZE $=6.9521(95 \%$ CL $2.5166-11.388)+0.3214(95 \%$ CL $0.2306-0.4121) \cdot$ DAY Based on the model parameters, an upper 95\% prediction interval was calculated for the max. population size estimation on the last days of the study, when we found the last genotype.

Based on unique genotypes, basic genetic measures were estimated: (i) for each locus the deviation from the Hardy-Weinberg Equilibrium and linkage disequilibrium were assessed using Fisher's exact test in Genepop v.4 (Raymond \& Rousset 1995, Rousset 2008), with the following settings: 10,000 dememorisation, 1,000 batches and 10,000 iterations; (ii) for each locus and for a combination of 9 loci, the Probability of Identity (the average probability that two unrelated individuals, randomly sampled from a population, will have the same genotype, P(ID)) was calculated using GenAlEx v. 6.501. Additionally, we also calculated the Probability of Identity with taking into account the genetic similarity among siblings (P(ID-Sibs)); (iii) mean values for basic genetic indices, i.e. the number of alleles $(A)$, observed $\left(H_{0}\right)$ and expected heterozygosity $\left(H_{\mathrm{E}}\right)$ (Nei 1978) and inbreeding coefficient $\left(F_{\mathrm{IS}}\right)$. These analyses were performed using GenAlEx and FSTAT version 2.9.3.2 (Goudet 2001).

\section{RESULTS}

Among the 156 samples, we successfully genotyped 92 samples (60\%). Among them, 9 samples were identified, based on their genotypes, as belonging to other species (the black grouse Lyrurus tetrix L. and the hazel grouse Tetrastes bonasia (L.)). Hence, we finally obtained 81 genotypes of the capercaillie. Within these data 34 unique genotypes were found 
(G1-G34, Table 1). Among them, 17 genotypes were found in more than one sample. The most frequent genotype (G6) was found in 18 samples. The distribution of genotypes throughout the study area was presented in Table 1 . In general, the genotypes were distributed around a single sampling site, instead of G6, which was found in two distant areas: Kulawiec and Piec; and G11 which was found in two nearby locations: Pańszczyca and Polana Waksmundzka. Based on these data, the MNA was 34 individuals.

Table 1. Distribution of microsatellite genotypes (G1-G34) throughout study area. Number of samples with particular genotype is given. Names of sampling sites as in Fig. 1, except of: BOB - Bobrowiec, KUL - Kulawiec, PYSZ Pyszna, JAF - Jaferowy, ZAR - Żar, PIEC - Piec, KON - Kondratowy, LG - Las Gąsienicowy, PAN - Pańszczyca, PW -- Polana Waksmundzka, CZUB - Czuba, ZAB - Żabie. $N_{\mathrm{C}}$ - number of samples collected, $N_{\mathrm{S}}-$ number of samples successfully genotyped, $N_{\mathrm{G}}$ - number of identified genotypes.

\begin{tabular}{|c|c|c|c|c|c|c|c|c|c|c|c|c|c|}
\hline & Grześ & BOB & KUL & PYSZ & JAF & ZAR & PIEC & KON & $\mathrm{LG}$ & PAN & PW & CZUB & $\mathrm{ZAB}$ \\
\hline$N_{C}$ & 1 & 26 & 19 & 1 & 10 & 2 & 16 & 10 & 4 & 30 & 2 & 13 & 1 \\
\hline$N_{S}$ & 0 & 15 & 12 & 1 & 7 & 1 & 15 & 3 & 4 & 15 & 1 & 5 & 0 \\
\hline$N_{G}$ & 0 & 6 & 3 & 1 & 2 & 1 & 3 & 2 & 3 & 9 & 1 & 5 & 0 \\
\hline G1 & & 5 &. & . &. &. &. &. & . & . & . & . & \\
\hline G2 & & 2 & . & . & . & . & . & . & . & . & . & . & \\
\hline G3 & & 2 & . & . & . & . & . & . & . & . & . & . & \\
\hline G4 & & 2 & . & . & . & . & . & . & . & . & . & . & \\
\hline G5 & & . & . & . & 4 & . & . & . & . & . & . & . & \\
\hline G6 & & . & 5 & . & . & . & 13 & . & . & . & . & . & \\
\hline G7 & & . & 6 & . & . & . & . & . & . & . & . & . & \\
\hline G8 & & . & . & . & . & . & . & . & . & 2 & . & . & \\
\hline G9 & & . & . & . & . & . & . & . & . & 2 & . & . & \\
\hline G10 & & . & . & . & 3 & . & . & . & . & . & . & . & \\
\hline G11 & & . & . & . & . & . & . & . & . & 2 & 1 & . & \\
\hline G12 & & 2 & . & . & . & . & . & . & . & . & . & . & \\
\hline G13 & & . & . & . & . & . & . & . & 2 & . & . & . & \\
\hline G14 & & . & . & . & . & . & . & 2 & . & . & . & . & \\
\hline G15 & & . & . & . & . & . & . & . & . & 2 & . & . & \\
\hline G16 & & . & . & . & . & . & . & . & . & 2 & . & . & \\
\hline G17 & & . & . & . & . & . & . & . & . & 2 & . & . & \\
\hline G18 & & . & . & . & . & . & . & . & . & . & . & 1 & \\
\hline G19 & & 1 & . & . & . & . & . & . & . & . & . & 1 & \\
\hline G20 & & . & . & . & . & . & . & . & . & . & . & 1 & \\
\hline G21 & & . & . & . & . & . & . & . & . & . & . & 1 & \\
\hline G22 & & . & . & . & . & . & . & . & . & . & . & 1 & \\
\hline G23 & & . & . & . & . & . & . & . & . & 1 & . & . & \\
\hline G24 & & . & . & . & . & . & . & . & . & 1 & . & . & \\
\hline G25 & & . & . & 1 & . & . & . & . & . & . & . & . & \\
\hline G26 & & . & . & . & . & . & . & $i$ & . & . & . & . & \\
\hline G27 & &. & . & . & . & . & . & . & $i$ &. & . & . & \\
\hline G28 & &. & & . & . & . & . & . & 1 & . & . & . & \\
\hline G29 & &. & & . & . & $i$ & . & . & . &. &. & . & \\
\hline G30 & &. & 1 &. &. & . &. &. &. &. &. & . & \\
\hline G31 & & . & . & . & . &. & . & . & . &. &. & . & \\
\hline G32 & & . & . & . & . &. & . & . & . & $\dot{1}$ &. & . & \\
\hline G33 & &. &. &. &. & . & $\dot{1}$ &. &. & . &. &. & \\
\hline G34 & & . & . & . & . & . & 1 & . & . & . & . & . & \\
\hline
\end{tabular}

The analysis in Capwire indicated that the area was inhabited by 54 birds (95\% C.I. 49-81 ind.). Among them 4 birds belonged to the category of individuals with a high probability of detection and 50 birds to the category of individuals with a low probability of detection. The regression model suggested 36-64 individuals in the population (Fig. 2).

The indicators of genetic diversity, estimated based on the microsatellite polymorphisms of 34 individuals, are shown in Table 2. All loci were polymorphic, with 3-6 alleles per locus. In two cases (locus TuT1 and Bg12), we found significant heterozygote deficiency. Accordingly, 
the population was not in Hardy-Weinberg Equilibrium. We did not find significant linkage disequilibrium among the investigated loci.

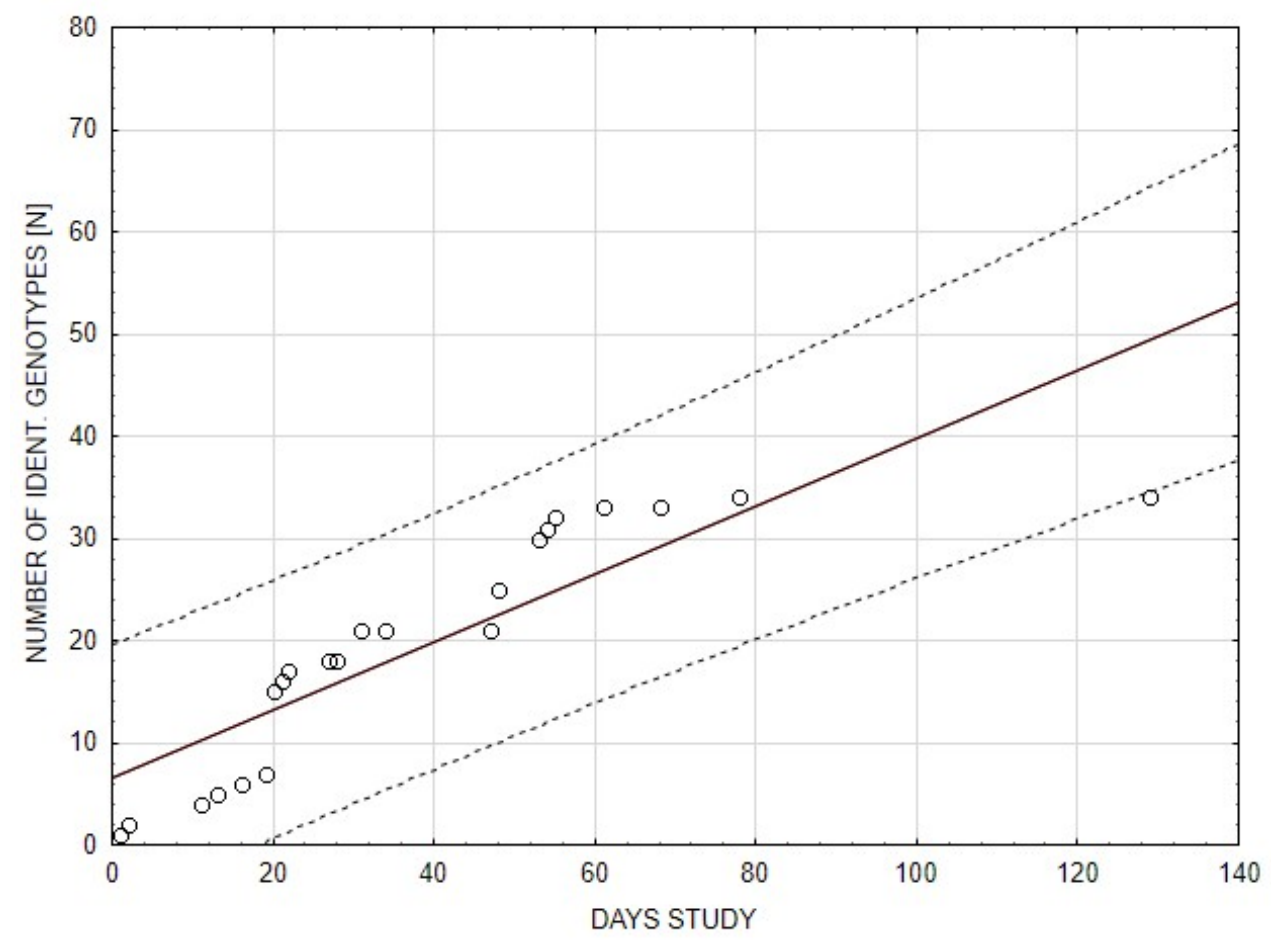

Fig. 2. Regression model of the relationships between the number of detected genotypes and numbers days of study; dotted line $-95 \%$ prediction intervals

Per locus, the Probability of Identity (P(ID)) ranged from 0.36 (locus TTT1) to as low as 0.08 (TuT4). For the combination of 9 loci, both P(ID) and P(ID-Sibs) were $7.38 \cdot 10^{-7}$ and 0.002 , respectively. Hence, according to our data, the expected number of different individuals with the same genotype was very low.

Table 2. Indices of genetic diversity in the population of the capercaillie from the Tatra National Park, estimated based on microsatellite polymorphisms of 34 individuals. $A$ - number of alleles per locus, $H_{\mathrm{O}}$ - heterozygosity observed, $H_{\mathrm{E}}$ - heterozygosity expected, HWE - P-values for HWE exact test for heterozygote deficiency/excess (ns - nonsignificant $[\mathrm{P}>0.05]), F_{\text {IS }}$ - fixation index $\left(*-F_{\text {IS }}\right.$ value significant after Bonferroni correction, 180 randomization, adjusted P-value $=0.0056$ ).

\begin{tabular}{cccccc}
\hline Locus & $A$ & $H_{\mathrm{o}}$ & $H_{\mathrm{E}}$ & $H W E$ & $F_{\text {IS }}$ \\
\hline BG16 & 5.00 & 0.636 & 0.659 & $\mathrm{~ns}$ & -0.007 \\
TTT1 & 5.00 & 0.412 & 0.419 & $\mathrm{~ns}$ & 0.084 \\
TuT2 & 5.00 & 0.529 & 0.602 & $\mathrm{~ns}$ & 0.078 \\
BG12 & 5.00 & 0.471 & 0.652 & 0.005 & 0.217 \\
TuT1 & 3.00 & 0.176 & 0.564 & $<0.001$ & $0.683^{*}$ \\
TuD4 & 4.00 & 0.485 & 0.638 & $\mathrm{~ns}$ & 0.040 \\
TuT4 & 6.00 & 0.765 & 0.784 & $\mathrm{~ns}$ & 0.020 \\
TuT3 & 5.00 & 0.353 & 0.376 & $\mathrm{~ns}$ & 0.037 \\
BG18 & 6.00 & 0.735 & 0.656 & $\mathrm{~ns}$ & -0.107 \\
Mean/overall & 4.89 & 0.507 & 0.594 & & 0.001 \\
\hline
\end{tabular}




\section{DISCUSSION}

Reliable estimates of population size have become important in monitoring and management for conservation (Williams et al. 2002, Royle \& Dorazio 2008). Invasive methods are often inappropriate in the case of endangered species and require multisession sampling, for example during subsequent seasons (Capture-Mark-Recapture) - the strategy difficult to achieve in the case of elusive and rare species. On the contrary, genetic tagging allows estimating population size based on samples collected during single session (Petit \& Valiere 2006). Accordingly, genotyping of non-invasivelly collected samples is an issue of increasing importance (Miller et al. 2005, Kéry et al. 2011, Mollet et al. 2015). Nevertheless, the strategy has its pitfalls. For example distinguishing among individuals in declining and small populations based on their genotypes can be challenging, because of the genetic similarity of individuals. Moreover, DNA obtained from non-invasive samples is prone to genotyping errors (Jacob et al. 2010). These problems may lead to over- or underestimating population size, resulting in inappropriate management decisions.

Field surveys suggested that the number of birds in the Tatra National Park is approximately 45 (Zwijacz-Kozica \& Zięba 2017). Our analysis, based on genetic data, indicated similar results: the Minimum Number of individuals Alive (MNA) was 34, the population size estimated based on genetic tagging was 54, and regression model suggested 36-64 individuals in the population. These indicate that our genotyping procedure performs well in estimating the abundance of the capercaillie in the investigated population. Indeed, genetic analysis of non-invasively collected samples provided insight into the demography and ecology of different caprecaillie populations (Jacob et al. 2010, Morán-Luis et al. 2014, Mollet et al. 2015).

In a previous study (Rutkowski et al. 2015), that analysed more than 200 non-invasive samples, collected during three subsequent seasons (2012-2014), 57 unique genotypes were found in the population from the Tatra National Park. Combining these estimates with current results, we can assume that the size of this population contains a range of 34-60 individuals. Other local populations are probably smaller, with 25-30 individuals reported for Gorce and 20 individuals for Babia Góra, however within Polica region there are an estimated 60 individuals (Żurek \& Armatys 2011). This constitutes the Tatra National Park as the main stronghold of the capercaillie in the Polish Carpathians.

The genetic diversity of the population from the Tatra National Park, estimated based on samples from 2016, was slightly lower than the values reported previously for 2012-2014 (Rutkowski et al. 2015, 2017), either in terms of the number of alleles or the level of heterozygosity. This could indicate that genetic diversity has been decreasing in the investigated population. It was shown that some local populations in the Carpathians have recently disappeared, while others are still decreasing in size (Saniga 2003, Mikoláš et al. 2015). The Slovakian population of the capercaillie in the Western Carpathians has been rapidly decreasing during the last thirty years, both in terms of number of individuals and leks (Saniga 2011). Hence, it is possible that a negative demographic trend and accompanied isolation and decrease of genetic diversity have also affected the capercaillie population in the Polish Carpathians. This study analysed genetic diversity in a sample of individuals from a single season, whereas higher values were found for pooled data from three different seasons (Rutkowski et al. 2017). Clearly, including samples from a longer period allowed more genetic polymorphism to be detected. Accordingly, multi-season analysis should effect in more precise estimation of population size, as more individuals would be detected. This could be especially important for species with different detection probability among individuals, for example due to behavioural differences. Such a detection probability bias was indeed suggested for the capercaillie (Mollet et al. 2015). On the other hand, non-invasive genetic 
tagging was shown to provide reliable estimates of population size, even based on data obtained from just one sampling occasion (Petit \& Valiere 2006, Mollet et al. 2015).

We found significant heterozygote deficiency in the investigated capercaillie population. Such a deviation from the Hardy-Weinberg Equlibrium could be caused by an internal genetic structure within a population, for example, by a large distance between leks, scattered around an extensive area. Indeed, genetic data suggested that the birds gather and stay within limited area, as we found only two cases of movement during the study period (genotypes G6 and G11). However, we rather suggest that the observed deficiency of heterozygotes results mainly from a deviation from the Hardy-Weinberg Equilibrium in locus TuT1. It was shown that this locus bears null alleles in the capercaillie (Jacob et al. 2010). The presence of null alleles is one of the factors decreasing heterozygosity in populations.

\section{ACKNOWLEDGEMENTS}

The study was supported by National Forest Funds, transferred to the Tatra National Park in 2016.

\section{REFERENCES}

Amos W. \& BALMFORD A. 2001. When does conservation genetics matter? Heredity 87: 257-265; DOI:10.1046/j.13652540.2001.00940.X

BajC M., ČAs M., Ballian D., Kunovac S., Zubić G., Grubešić M., Zhelev P., Paule L., Grebenc T. \& KrAigher H. 2011. Genetic differentiation of the Western Capercaillie highlights the importance of SouthEastern Europe for understanding the species phylogeography. PLoS ONE 2011; 6, e23602; DOI: 10.1371/journal.pone.0023602.

BIRDLIFE InTERnAtional. Tetrao urogallus. The IUCN Red List of Threatened Species 2012. Available at: http://dx.doi.org/10.2305/IUCN.UK.2012-1.RLTS.T22679487A40101999.en (14 Jan 2016).

CAizergues A., Dubois S., Mondor G. \& RAsplus J-F. 2001. Isolation and characterisation of microsatellite loci in black grouse (Tetrao tetrix). Molecular Ecology Notes 1: 36-38; DOI: 10.1046/j.1471-8278.2000.00015.x

DeSAlle R. \& AmAto G. 2004. The expansion of conservation genetics. Nature Reviews. Genetics 5: 702-712; DOI: $10.1038 /$ nrg1425

GOUDET J. 2001. FSTAT V2.9.3, a program to estimate and test gene diversities and fixation indices. Available at: http://www.unil.ch/izea/softwares/fstat.htlm

Haig S. M., Bronaugh W. M., Crowhurst R. S., D'Elia J. D., Eagles-Smith C. A., Epps C. W., Knaus B., MilleR M. P, Moses M. L., OYleR-MCCANCE S., Robinson W. D. \& SidlausKas B. 2011. Genetic applications in avian conservation. The Auk 128: 205-229; DOI:10.1525/auk.2011.128.2.205

HEDRICK P. W. 2001. Conservation genetics: Where are we now? Trends in Ecology and Evolution 16: 629-636; DOI: 10.1016/S0169-5347(01)02282-0

Jacob G., Debrunner R., Gugerli F., Schmid B., \& Bollmann K. 2010. Field surveys of capercaillie (Tetrao urogallus) in the Swiss Alps underestimated local abundance of the species as revealed by genetic analyses of non-invasive samples. Conservation Genetics 11(1): 33-44; DOI 10.1007/s10592-008-9794-8

Kéry M., GARdner B., StoecKle T., Weber D. \& RoYle J. A. 2011. Use of Spatial Capture-Recapture Modeling and DNA Data to Estimate Densities of Elusive Animals. Conservation Biology 25(2): 356-364; DOI: 10.1111/j.15231739.2010.01616.x

Kristensen T. N., Pedersen K. S., Vermeulen C. J. \& LoeschcKe V. 2010. Research on inbreeding in the "omic” era. Trends in Ecology and Evolution 25: 44-52; DOI: 10.1016/j.tree.2009.06.014

LiukKonen-Anttila T., RAtti O., Kvist L., Helle P. \& Orell M. 2004. Lack of genetic stucturing and subspecies differentiation in the capercaillie (Tetrao urogallus) in Finland. Annales Zoologici Fennici 41:619-643.

MÄKi-PetÄYs H., Corander J., AAlto J., LiUkKonen T., Helle P. \& Orell M. 2007. No genetic evidence of sexbiased dispersal in a lekking bird, the capercaillie (Tetrao urogallus). Journal of Evolutionary Biology 20: 865-873; DOI: 10.1111/j.1420-9101.2007.01314.x

MARTINEZ-CruZ B. 2011. Conservation genetics of Iberian raptors. Animal Biodiversity and Conservation 34: $341-353$.

McCartney-Melstad E. \& Shaffer H. B. 2015. Amphibian molecular ecology and how it has informed conservation. Molecular Ecology 24: 5084-5109; DOI: 10.1111/mec.13391

Mikoláš M., Svitokc M., TEJKale M., LeitÃof P. J., Morrisseya R. C., Svoboda M., SEedre M \& FonTAine J. B. 2015. Evaluating forest management intensity on an umbrella species: Capercaillie persistence in central Europe. Forest Ecology and Management 354: 26-34; DOI: 10.1016/j.foreco.2015.07.001 
Miller C. R., JOYCE P. \& WAITS L. P. 2005. A new method for estimating the size of small populations from genetic mark-recapture data. Molecular Ecology 14 (7): 1991-2005; DOI: 10.1111/j.1365-294X.2005.02577.x

Mollet P., Kéry M., Gardner B., PAsinelli G. \& Royle J. A. 2015. Estimating population size for Capercaillie (Tetrao urogallus L.) with spatial Capture-Recapture Models based on genotypes from one field sample. PLoS ONE 10 (6): e0129020; DOI: 10.1371/journal.pone.0129020

Morán-Luis M., Fameli A., Blanco-Fontao B., Fernández-Gil A., Rodríguez-Muñoz R., Quevedo M. \& BAÑUELOS M. J. 2014. Demographic status and genetic tagging of endangered Capercaillie in NW Spain. PLoS ONE 9(6): e99799; DOI: 10.1371/journal.pone.0099799

Morin P. A., Martien K. K., Archer F. I., Cipriano F., Steel D., Jackson J. \& TAYlor B. L. 2010. Applied conservation genetics and the need for quality control and reporting of genetic data used in fisheries and wildlife management. Journal of Heredity 101: 1-10; doi: 10.1093/jhered/esp107

NEI M. 1978. Estimation of average heterozygosity and genetic distance from a small number of individuals. Genetics 89: 583-589.

PeAKall R. \& Smouse P. E. 2006. GenAlEx 6.0: genetic analysis in Excel. Population genetic software for teaching and research. Molecular Ecology Notes 6: 288-295; DOI: 10.1111/j.1471-8286.2005.01155.x

PEAKAll R. \& SMouse P. E. 2012. GenAlEx 6.5: genetic analysis in Excel. Population genetic software for teaching and research-an update. Bioinformatics 28: 2537-2539; DOI: 10.1093/bioinformatics/bts460

Pennell M. W., Stansbury C. R., WAits L. I. \& Miller C. R. 2013. Capwire: a R package for estimating population census size from non-invasive genetic sampling. Molecular Ecology Resources 13: 154-157; DOI: 10.1111/17550998.12019

PetiT E. \& VALIERE N. 2006. Estimating population size with noninvasive Capture-Mark-Recapture data. Conservation Biology 20: 1062-1073; DOI: 10.1111/j.1523-1739.2006.00417.x

Piertney S. B. \& HöGlund J. 2001. Polymorphic microsatellite DNA markers in black grouse (Tetrao tetrix). Molecular Ecology Notes 1: 303-304; DOI: 10.1046/j.1471-8278.2001.00118.x

RAYMOND M. \& ROUSSET F. 1995. GENEPOP (version 1.2): population genetics software for exact tests and ecumenicism. Journal of Heredity 86: 248-249; DOI: 10.1093/oxfordjournals.jhered.a111573

Regnaut S., Christe P., Chapuisat M. \& Fumagalli L. 2006a. Genotyping faeces reveals facultative kin association on capercaillie’s leks. Conservation Genetics 7: 665-674; DOI 10.1007/s10592-005-9097-2

REgnAUT S., LUCAS F. S. \& FUMAGALLi L. 2006b. DNA degradation in avian faecal samples and feasibility of noninvasive genetic studies of threatened capercaillie populations. Conservation Genetics 7: 449-453; DOI 10.1007/s10592-005-9023-7

RousSET F. 2008. Genepop'007: a complete re-implementation of the Genepop software for Windows and Linux. Molecular Ecology Resources 8: 103-106; DOI: 10.1111/j.1471-8286.2007.01931.x

Royle J. A. \& Dorazio R. M. 2008. Hierarchical modeling and inference in ecology. Elsevier Academic, Press, Burlington, MA. 464 pp; DOI: 10.1016/B978-0-12-374097-7.50001-5

RutKowsKi R., Keller M. \& JagOŁKOWSKa P. 2007. Populacje i podgatunki - genetyka molekularna w badaniach europejskich głuszcowatych Tetraonidae. Notatki Ornitologiczne 48: 260-274.

RUTKOWSKI R., KRZAN P. \& SUCHECKA E. 2015. Charakterystyka genetyczna populacji głuszca w Tatrzańskim Parku Narodowym na tle innych karpackich populacji gatunku [Population genetic of Capercaillie from Tatra National Park in comparison with other Carpathian strongholds]. Pp. 47-52. In: CHROBAK A. \& GoDzIK B. (eds), Nauka Tatrom. Vol. 2. Nauki Biologiczne. Materiały V Konferencji „Przyroda Tatrzańskiego Parku Narodowego a Człowiek” Zakopane, 24-26.09.2015. Tatrzański Park Narodowy \& Polskie Towarzystwo Przyjaciół Nauk o Ziemi, Oddział Krakowski, Zakopane 74 pp. [In Polish]

RutKowski R., NiEwĘGŁowsKi H., DZIEDZIC R., KMIEĆ M. \& GoŹDZIEwSKi J. 2005. Genetic variability of Polish population of the Capercaillie Tetrao urogallus. Acta Ornithologica 40: 27-34; DOI: 10.3161/068.040.0108

RutKowski R., ZAwAdZKa D., SuCheCKA E. \& MERTA D. 2017. Conservation Genetics of the Capercaillie in Poland - Delineation of Conservation Units. PLoS ONE 12 (4): e0174901; doi: 10.1371/journal.pone.0174901

SANIGA M. 2003. Causes of the population decline in Capercaillie (Tetrao urogallus) in the West Carpathians. Biologia (Bratislava) 58: 265-273.

SANIGA M. 2011. Why the capercaillie population (Tetrao urogallus L.) in mountain forests in the Central Slovakia decline? Folia Oecologica 38: 110-117.

SARRE S. D. \& GEORGES A. 2009. Genetics in conservation and wildlife management: A revolution since Caughley. Wildlife Research 36: 70-80; DOI: 10.1071/WR08066

SEGELBACHER G. 2002. Noninvasive genetic analysis in birds: testing reliability of feather samples. Molecular Ecology Notes 2: 367-369; DOI: 10.1046/j.1471-8286.2002.00180.x-i2

SEgELbaCHER G., HöGLUND J. \& STORCH I. 2003. From connectivity to isolation: genetic consequences of population fragmentation in capercaillie across Europe. Molecular Ecology 12: 1773-1780; DOI: 10.1046/j.1365294X.2003.01873.x

Segelbacher G., Manel S. \& Tomiuk J. 2008. Temporal and spatial analyses disclose consequences of habitat fragmentation on the genetic diversity in capercaillie (Tetrao urogallus). Molecular Ecology 17: 2356-2367; DOI: 10.1111/j.1365-294X.2008.03767.x 
Segelbacher G., Paxton R. J., Steinbruck G., Trontelu P. \& StOrch I. 2000. Characterization of microsatellites in capercaillie Tetrao urogallus (AVES). Molecular Ecology 9: 1934-1935; DOI: 10.1046/j.1365294x.2000.0090111934.x

Segelbacher G., Wegge P., Sivkov A. V. \& Höglund J. 2007. Kin groups in closely spaced capercaillie leks. Journal of Ornithology 148: 79-84; DOI: 10.1007/s10336-006-0103-3

Selkoe K. A. \& ToOnen R. J. 2006. Microsatellites for ecologists: A practical guide to using and evaluating microsatellite markers. Ecology Letters 9: 615-629; DOI: 10.1111/j.1461-0248.2006.00889.x

STORCH I. 2007a. Conservation Status of Grouse Worldwide: an update. Wildlife Biology 13: 5-12; DOI: 10.2981/0909-6396(2007)13[5:CSOGWA]2.0.CO;2

Storch I. 2007b. Grouse - Status Survey and Action Plan 2006-2010 IUCN. Gland Switzerland and Cambridge UK. and World Pheasant Association, Fordinbridge, UK. 112 pp.

TABerlet P., LuikART G. \& WAits L. P. 1999. Noninvasive genetic sampling: Look before you leap. Trends in Ecology and Evolution 14 (8): 293-332; DOI: 10.1016/S0169-5347(99)01637-7

Williams B., NiCHOLS J. D \& CONROY M. 2002. Analysis and management of animal populations. Elsevier Academic Press, San Diego, CA. 817 pp.

ZWIJACZ-KoZICA T. \& ZIĘBA F. 2017 (2015). Zwierzęta Tatrzańskiego Parku Narodowego w roku 2015. Wierchy 81: $196-202$.

ŻUREK Z. \& ARMATYS P. 2011. Występowanie głuszca Tetrao urogallus w polskich Karpatach Zachodnich - wnioski z monitoringu w latach 2005-2010 oraz końcowa ocena liczebności karpackich subpopulacji głuszca i cietrzewia [The occurence of Capercillie in Polish Western Carpathians - conclusions from the monitoring in the years 20052010 and the final assessment of the quantity of Carpathians subpopulations of Capercaillie and Black Grouse]. Studia i Materiały CEPL, Rogów 13 (2): 229-240. [In Polish]

\section{STRESZCZENIE}

\section{[Genetyka konserwatorska głuszca w Polsce - ocena wielkości populacji z Tatrzańskiego Parku Narodowego na podstawie genotypowania prób nieinwazyjnych]}

Wiedza o wielkości populacji ma istotne znaczenie dla ochrony gatunków zagrożonych. Genotypowanie mikrosatelitarne prób nieinwazyjnych jest często wykorzystywane do oceny liczby osobników występujących na danym obszarze. W odróżnieniu od tradycyjnych metod obserwacyjnych lub odłowu i znakowania, strategia oparta na profilowaniu genetycznym pozwala śledzić poszczególne osobniki bez bezpośredniego kontaktu z nimi, wyznaczać minimalną liczbę osobników żyjących na terenie badań (MNA), a także szacować wielkość populacji na podstawie jednej sesji gromadzenia danych. Głuszec (Tetrao urogallus) jest kurakiem leśnym zagrożonym wyginięciem w wielu krajach Europy. W Polsce występuje w czterech izolowanych populacjach, wśród których populacja karpacka uważana jest za najliczniejszą. Tatrzański Park Narodowy stanowi prawdopodobnie główną ostoję głuszca w polskiej części Karpat, ale dokładna liczba żyjących tam osobników nie jest znana. Dane obserwacyjne sugerują występowanie około 45 głuszców. Celem badań było więc oszacowanie liczby osobników głuszca, występujących na terenie Tatrzańskiego Parku Narodowego na podstawie genotypowania prób nieinwazyjnych. Materiał genetyczny (DNA) był izolowany z piór i odchodów $(n=150)$ zebranych na terenie Parku w 2016 roku. Profile genetyczne określano w 9 loci mikrosatelitarnych. Wiarygodne wyniki uzyskano w przypadku 81 prób, wśród których stwierdzono 34 genotypy unikatowe (MNA =34). Zastosowanie modelu odpowiadającego badaniu typu odłów-znakowanie-odłów (CMR) w programie Capwire wykazało, że w badanej populacji występuje ok. 50 osobników, natomiast regresja pomiędzy liczbą dni badań i liczbą stwierdzonych genotypów sugerowała występowanie maksimum 36-64 osobników. Są to wartości bardzo zbliżone do wielkości populacji z Tatrzańskiego Parku Narodowego, szacowanej na podstawie obserwacji. Wskazuje to, że genotypowanie prób nieinwazyjnych stanowi przydatną metodę oceny liczebności głuszca. 